\title{
Sweetvetch Seed Germination
}

EDWARD F. REDENTE

\section{Abstract}

Sweetvetch (Hedysarum boreale Nutt. var. boreale) is a potentially important revegetation species for drastically disturbed lands and range improvements in western North America. The germination of sweetvetch was studied under various temperature, light, and moisture conditions. It was found that sweetvetch can germinate under a wide range of temperature and light conditions following physical scarification of the seed coat. Under constant temperatures optimum germination occurred at $15^{\circ} \mathrm{C}$ and $20^{\circ} \mathrm{C}$, while under alternating temperature optimum germination occurred at $15-25^{\circ} \mathrm{C}$ and $20-15^{\circ} \mathrm{C}$ (for 8 hours and 16 hours, respectively, in each case). Dark treatments resulted in greater germination than light treatments. When temperature and light conditions were held constant and moisture conditions varied, the germination of sweetvetch declined rapidly at osmotic potentials below -7.5 bars.

Sweetvetch (Hedysarum boreale Nutt.) is a native legume that has a wide range of adaptability and appears to possess many characteristics desirable for disturbed land reclamation and range improvement. The use of sweetvetch in reseeding work has been limited because of a scarcity of information about the species and limited supplies of plant materials.

Hedysarum boreale was first described by Nuttall (1818). In 1902 Fedtschenko published a world revision of the genus Hedysarum, but his coverage of American species was limited. Rydberg (1896) also attempted to describe Hedysarum in the Rocky Mountains and adjacent plains but according to Northstrom and Welsh (1970) failed to recognize the two natural subdivisions of the genus which were described by Rollins (1940).

The most recent and complete account of the Hedysarum boreale complex is by Northstrom and Welsh (1970). In this revision the authors attempt to depict the pattern of morphological variation and geographical distribution of natural populations of the Hedysarum boreale complex and also to assign valid names to each specific entity.

Some of the first reseedings made with sweetvetch failed to become established (USDA 1937). However, adaptability trials by Plummer et al. (1968) and Sims and Redente (1974) indicated good establishment, growth, and survival in mixed mountain shrub, pinyon-juniper, and sagebrush vegetation types in both Colorado and Utah. Plummer et al. (1968) reported that sweetvetch is adapted to both sandy and clayey soils, on neutral and acidic soils, and on alkaline soils in saltbush and greasewood communities. Sweetvetch is an appealing forb for revegetation primarily because it is a native species and has nitrogen-fixing abilities (Redente 1980). The number of native legumes that are available or show promise as revegetation species is limited. However, the need for native legumes is great and species such as sweetvetch can fill an important role in disturbed land reclamation and range improvement work.

The present investigation was made to provide basic information on the autecology of sweetvetch. The objectives of this study

\footnotetext{
Author is assistant professor, Department of Range Science, Colorado State UniAuthor is assistant profes
versity, Fort Collins 80523 .

Research was supported by the U.S. Department of Energy under Contract No. DE-AS02-76EV04018

Manuscript received November 7, 1980
}

were to evaluate the germination characteristics of sweetvetch $(H$. boreale var. boreale) under constant and fluctuating temperatures and the possible interaction that would exist between light and temperature. Germination responses were also examined under various moisture stress conditions.

\section{Methods}

Sweetvetch seed was obtained from three sepa rate sources. Seed from one source was collected at an elevation of $1,372 \mathrm{~m}$ near Salt Lake City, Utah, in the fall of 1976. A second collection was made near Orem, Utah, in the fall of 1978 at an elevation of $1,341 \mathrm{~m}$. The third source was obtained in 1978 from the USDA Soil Conservation Service Plant Materials Center in Bismarck, N.D. The seed was harvested in 1960 and originated from a collection made in Musselshell County, Mont.

Preliminary trials with each seed source indicated that the existence of a hard seed coat prevented imbibitional swelling in the presence of adequate water. To overcome seed coat dormancy a scarification study was implemented using a scarifer consisting of a small metal drum lined with abrasive paper. The procedures outlined by Townsend and McGinnies (1972) were used, and an air pressure of $2.5 \mathrm{~kg} / \mathrm{cm}^{2}$ (35 psi) was identified as the optimum pressure for propelling seeds through the abrasive drum to provide an adequate scarification treatment. Without this scarification treatment germination under laboratory conditions was negligible. All seed used in this study was scarified.

Seed germination of the three sources of sweetvetch was then studied at six constant and six fluctuating temperatures under light and dark conditions. The six constant temperatures were $5,10,15$, 20,25 , and $30^{\circ} \mathrm{C}$; alternating temperatures were 15-20, 20-15, $15-25,25-15,20-25$, and $25-20^{\circ} \mathrm{C}$ ( 16 and 8 hours, respectively). The light treatment during alternating temperatures was associated with the 8-hour time period.

The same sources of sweetvetch seed were also subjected to negative osmotic potentials during germination after optimum temperature and light conditions were identified. Substrate water potentials of $-0.3,-5,-7.5,-10,-12.5$, and -15 bars were prepared by dissolving appropriate amounts of polyethylene glycol (PEG4000) in distilled water according to procedures of Kidd et al. (1977) and Mexal and Reid (1973). Following the preparation of these aqueous solutions the seed was incubated in the dark at $15^{\circ} \mathrm{C}$.

In all germination tests, four replications of 100 seeds each were arranged in growth chambers in completely randomized designs. Plastic boxes measuring $13 \times 13.5 \times 3.5 \mathrm{~cm}$ with tightly fitting lids were used to contain a layer of creped cellulose (Kimpac), one sheet of blotter paper, $100 \mathrm{ml}$ of tap water or a mixture of PEG and distilled water, and 100 seeds of a particular sweetvetch source. All seeds were lightly dusted with thiram following the scarification treatment to reduce fungal attack. Germination counts were made daily from the 1 st through 28 th day. Seeds were considered to have germinated when the radicle emerged $1 \mathrm{~cm}$.

Data from temperature, light, and osmotic potential trials were subjected to analysis of variance procedures. Tukey's $Q$ test at the 0.01 level was used to test differences between means. Multiple regression techniques were used to determine the relationship between percent germination and osmotic potential. 


\section{Results and Discussion}

\section{Response to Constant Temperature}

All three seed sources of sweetvetch responded similarly to the range of constant temperatures tested. The highest germination was recorded at $15^{\circ} \mathrm{C}$ and $20^{\circ} \mathrm{C}$ for both light and dark conditions (Fig. 1). The lowest germination occurred at the two extreme temperatures of $5^{\circ} \mathrm{C}$ and $30^{\circ} \mathrm{C}$. Sweetvetch had $81.5 \%$ germination at $15^{\circ} \mathrm{C}$ and $81.0 \%$ germination at $20^{\circ} \mathrm{C}$ after averaging all seed sources together. The mid-range temperatures $(10,15,20$, and $\left.25^{\circ} \mathrm{C}\right)$ stimulated significantly $(P=.01)$ more germination than the high extreme temperature of $30^{\circ} \mathrm{C}$ and the low extreme temperature of $5^{\circ} \mathrm{C}$.

Seed that was obtained from Utah responded with significantly $(P=.01)$ higher germination percentages than the seed that originated in Montana (Fig. 1). The response of the two sources from Utah was similar. The Montana source had significantly $(P=.01)$ less overall germination than the Utah sources, but the trend across temperatures was similar to the seed sources from Utah in that germination was lower for the two extreme temperatures. The main reason for the lower germination percentage associated with the Montana seed was attributed to seed age. This seed was originally harvested in 1960 and not tested until 1979. A tetrazolium test indicated a total viability of $65 \%$. The Utah seed sources were harvested in 1976 and 1978. Tetrazolium tests on these seed sources indicated viability levels of $94 \%$ for both sources.

When averaged over all temperatures and sources the dark treatment ( 24 hours dark) gave significantly $(P=.01)$ greater germination than when light was provided for an 8-hour period. The response of each source to the presence or absence of light at each temperature can be seen in Figure 2. Germination was higher under dark conditions than under 8 hours of light for the Montana seed except at $15^{\circ} \mathrm{C}$. The difference at this temperature between light and dark was not significant $(P=.01)$. In fact, if germination response at individual temperatures is observed, then there are no significant $(P=.01)$ differences between light and dark. The same response is evident for the two seed sources from Utah.

An important factor in assessing seed germination is the rate at which germination occurs. Ideal temperature and moisture conditions last for only short periods of time under field conditions. Therefore, a species that can respond quickly to favorable soil

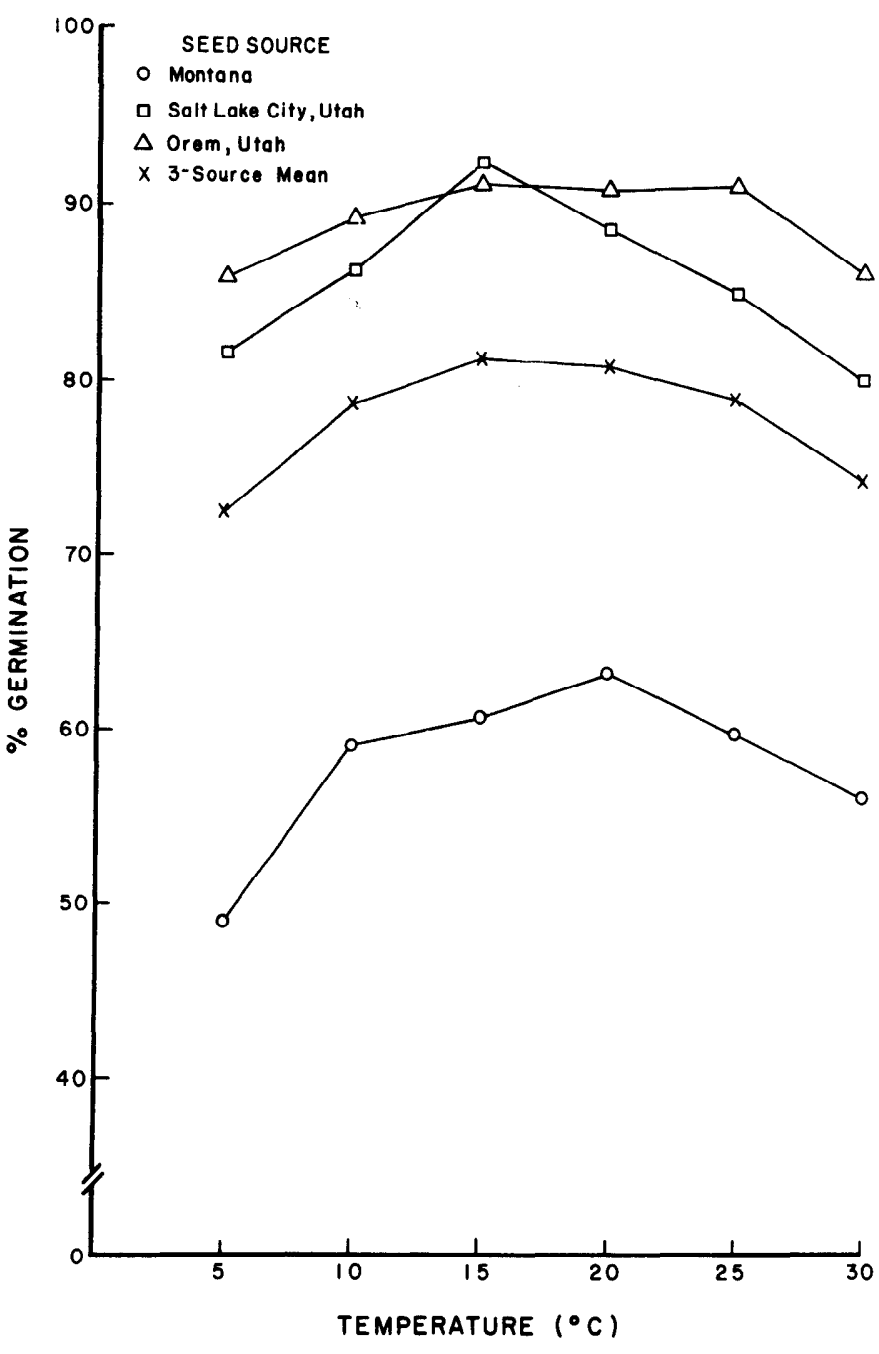

Fig. 1. Germination response of three seed sources and their group mean at six constant temperatures averaged over light and dark treatments.
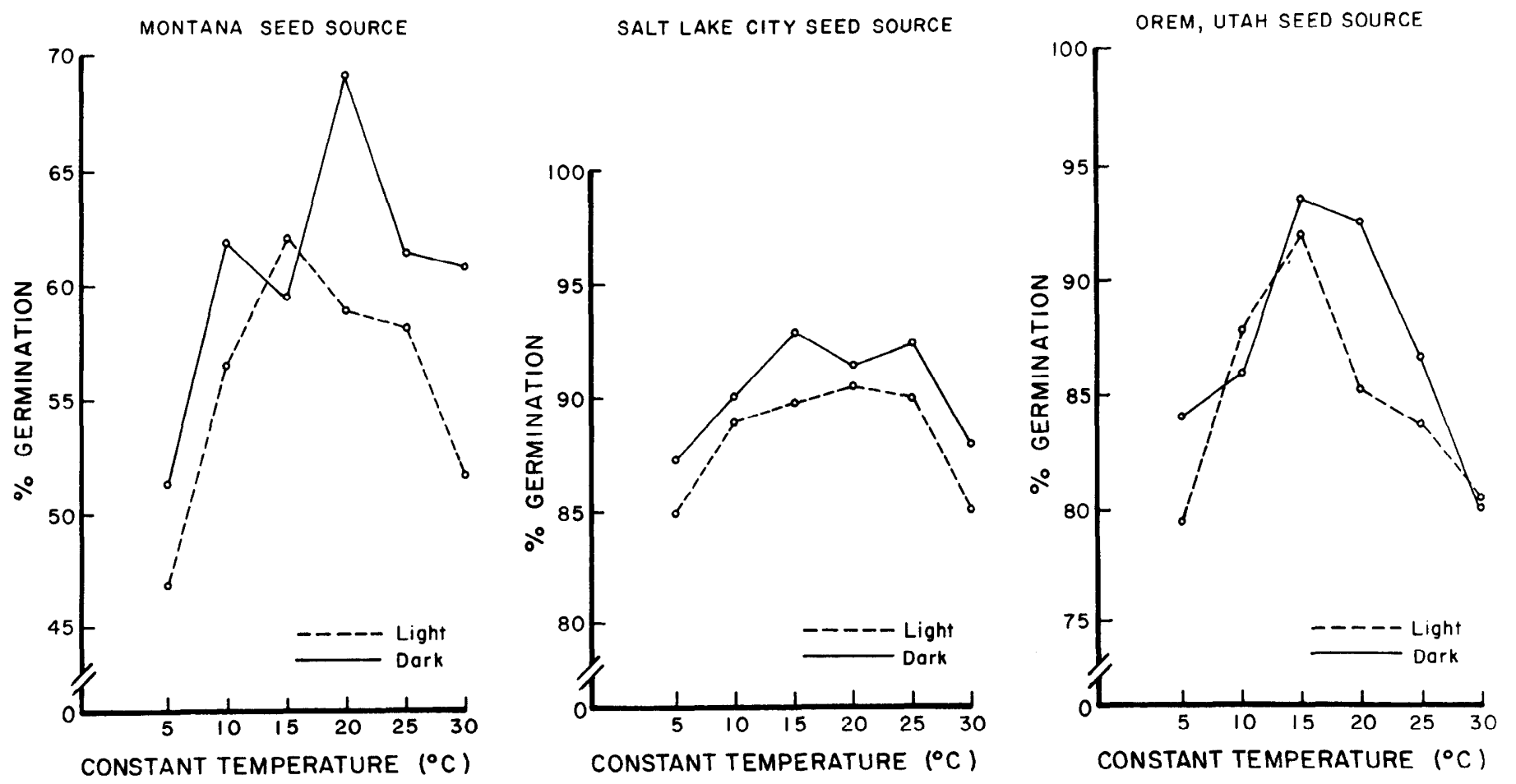

Fig. 2. Germination response of each seed source to six constant temperatures under light and dark conditions. 
moisture and temperature conditions may be the species that has the greatest potential in revegetation. It is also important to know the temperature and moisture conditions that will stimulate the most rapid germination. This type of information will provide guidelines to the proper time of seeding in order to take advantage of optimal environmental conditions. The graphical presentation (Fig. 3) shows that the germination rate is relatively slow at $5^{\circ} \mathrm{C}$ and $10^{\circ} \mathrm{C}$ when compared to the warmer temperatures. At a low temperature $\left(5^{\circ} \mathrm{C}\right)$ germination does not begin until the fifth or sixth day depending on the seed source. At this temperature it takes 8 days for $50 \%$ of the seed to germination. At $10^{\circ} \mathrm{C}$ it takes approximately 7 days for $50 \%$ seed germination to occur. This length of time may not be acceptable under field conditions because favorable moisture conditions may not last that long. However, in areas where the soil becomes saturated in the spring from snow melt and temperatures are still rather cool it would be possible to get a substantial amount of germination and emergence early in the growing sea son. Germination rate at the higher temperatures $\left(15,20,25\right.$, and $\left.30^{\circ} \mathrm{C}\right)$ was relatively rapid with approximately $50 \%$ of the seeds germinating on Day 3 at $15^{\circ} \mathrm{C}$, on Day 2 at $20^{\circ} \mathrm{C}$, on Day 3 at $25^{\circ} \mathrm{C}$, and on Day 4 at $30^{\circ} \mathrm{C}$.

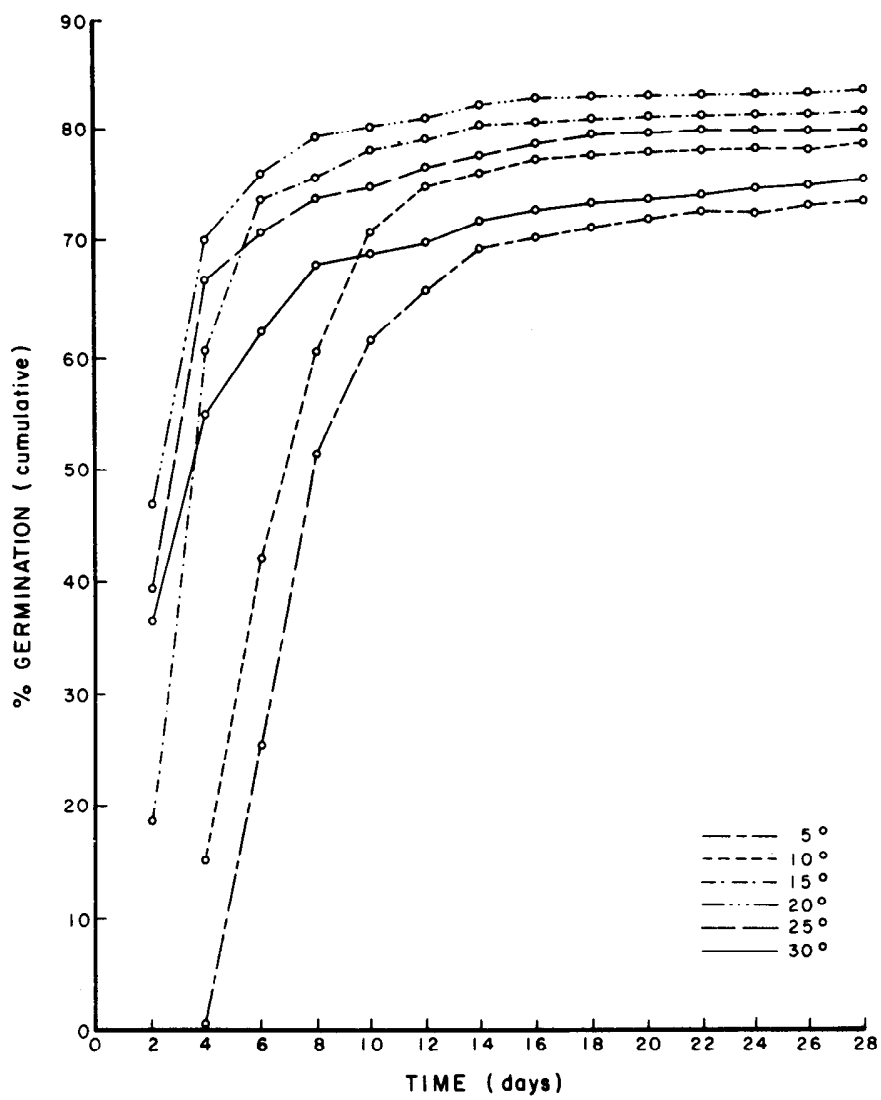

Fig. 3. Germination rate averaged over three sources and plotted for all six constant temperatures.

\section{Response to Fluctuating Temperature}

The effects of six fluctuating temperatures were tested under both light and dark treatments. The temperatures selected were based on the response of sweetvetch to constant temperatures. The optimum constant temperature appears to be somewhere between $15^{\circ} \mathrm{C}$ and $25^{\circ} \mathrm{C}$, and fluctuating temperature regimes were therefore developed using combinations of these values. The only treatment effects that were significant included differences between seed sources and a temperature $\times$ light interaction. The two sources of seed from Utah had significantly $(P=.01)$ higher germination across all temperatures and light treatments when compared to the Montana source, as expected. Sweetvetch seeds germinated better under dark conditions at 15-25, 20-15, 20-25, and 25-20 $\mathrm{C}$ (Fig. 4). When exposed to 8 hours of light, seed germinated better at 25-15

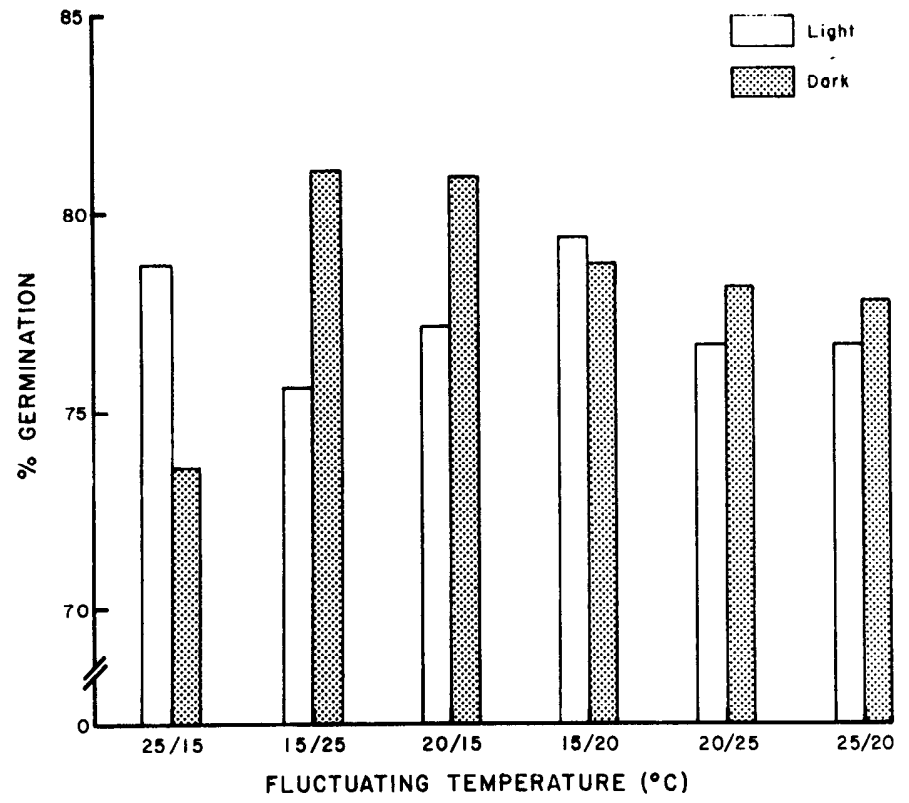

Fig. 4. Germination response at six fluctuating temperatures for both light and dark conditions.

and $15-20^{\circ} \mathrm{C}$. Germination at $15-25^{\circ} \mathrm{C}$ and $20-15^{\circ} \mathrm{C}$ under dark conditions was significantly $(P=.01)$ higher than under light conditions. Germination under light conditions at $25-15^{\circ} \mathrm{C}$ was significantly $(P=.01)$ higher than germination at the same temperature under dark conditions. It appears that the optimum temperature and light condition across all seed sources is $15-25^{\circ} \mathrm{C}$ or $20-15^{\circ} \mathrm{C}$ under dark conditions.

\section{Response to Water Stress}

In general, sweetvetch germination decreases with decreasing osmotic potential (Fig. 5). This decrease in germination does not become significant $(P=.01)$ until -5 bars osmotic potential is

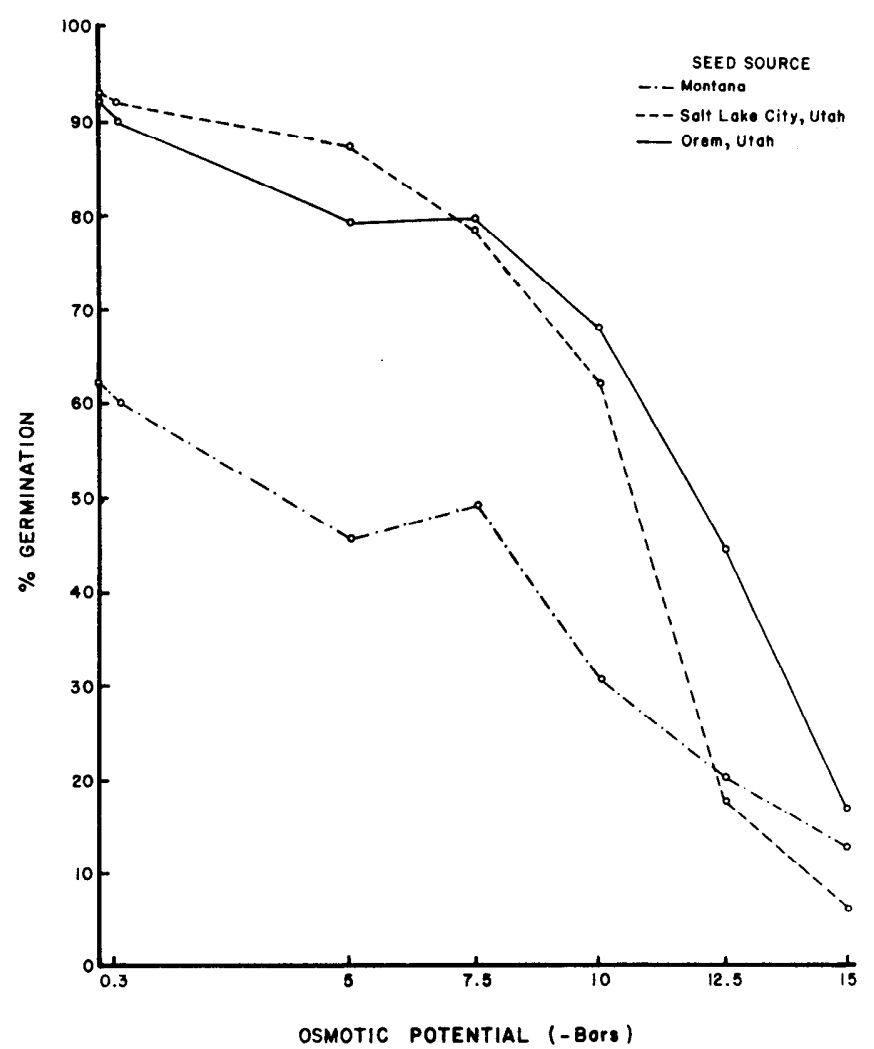

Fig. 5. Germination response for each seed source under various moisture conditions. 
reached with the seed source from Montana. The percent germination of the Utah seed was significantly $(P=.01)$ reduced at -10 bars. Germination at -5 and -7.5 bars was similar. However, at osmotic potentials less than -7.5 bars the percent germination of sweetvetch is reduced rather markedly.

Sweetvetch can germinate at rather low osmotic potentials, if temperature is not limiting. The interaction of temperature and osmotic potential was not studied, but osmotic potential becomes more prominent as temperature becomes less favorable (McGinnies 1960). The ability of sweetvetch to germinate under comparatively low osmotic potentials does not necessarily indicate that mature sweetvetch plants are drought tolerant. However, because of the nature of its root system and its occurrence in rather dry habitats, it can be conjectured that sweetvetch is at least moderately drought tolerant.

A regression analysis was used to determine the relationship between percent germination and osmotic potential. The analysis indicated that the relationship with the Montana source was linear while the Utah sources had highly significant quadratic relationships. Figure 6 illustrates the regression line generated from the Salt Lake City seed source. The coefficient of determination for the regression of percent germination on osmotic potential was 0.96 , and the regression was significant at the .01 level of probability. It can be readily seen from this regression that the relationship between seed germination and osmotic potential is positive when osmotic potentials are less than -5 bars. However, sweetvetch germination does not appear to be affected by stress at osmotic potentials greater than -5 bars. The same response was evident with the second source of seed from Utah; however, the Montana seed had a positive relationship between seed osmotic potential when germination and osmotic potentials were lower than -0.3 bar.

\section{Conclusion}

Sweetvetch can germinate under a wide range of temperature and light conditions. The overall germination of three sources of

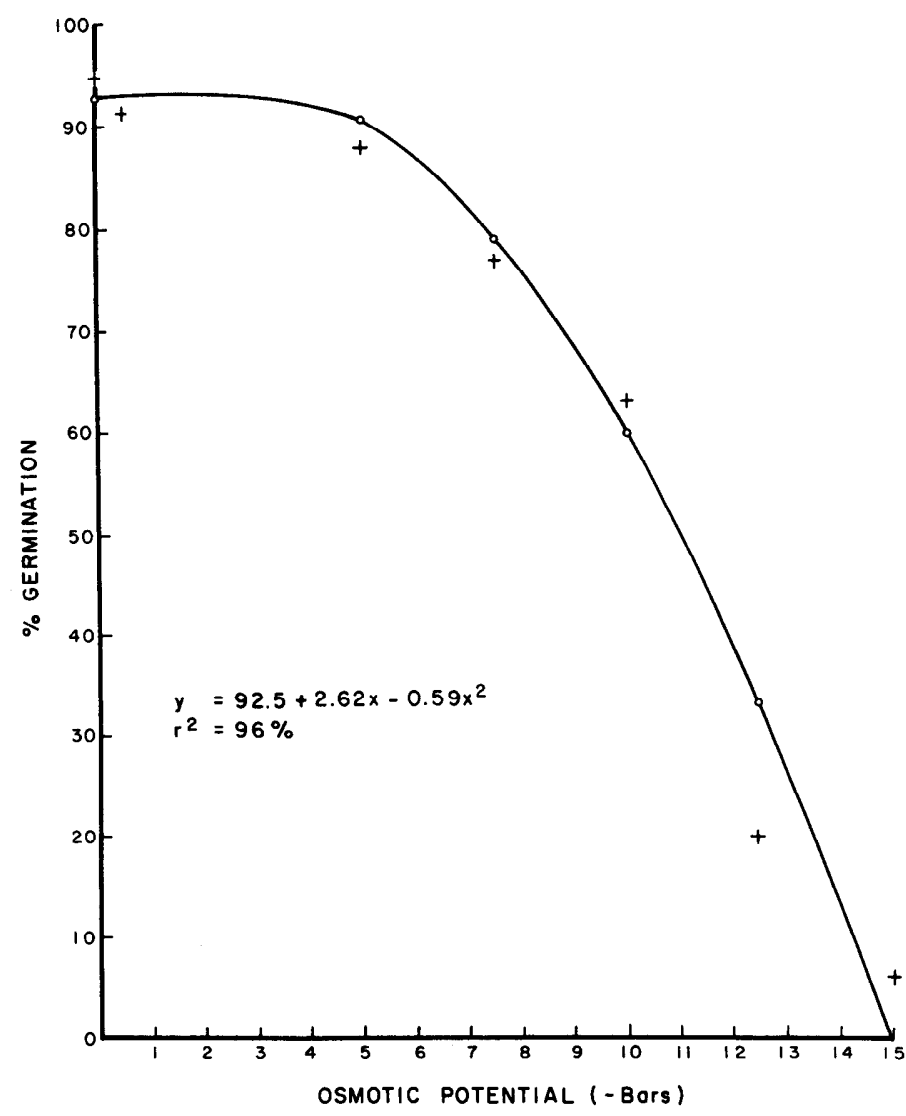

Fig. 6. Relationship between percent germination and osmotic potential for Salt Lake City seed source. sweetvetch seed at six constant temperatures was: $72 \%$ at $5^{\circ} \mathrm{C}, 78 \%$ at $10^{\circ} \mathrm{C}, 82 \%$ at $15^{\circ} \mathrm{C}, 79 \%$ at $25^{\circ} \mathrm{C}$, and $74 \%$ at $30^{\circ} \mathrm{C}$. The values were averaged over light and dark treatments; but, in general, the dark treatment resulted in greater germination when compared to 8 hours of light. Based upon percent germination it appears that $15^{\circ} \mathrm{C}$ under dark conditions would be the optimum temperature for sweetvetch germination. However, if the rate of germination is taken into account, then optimum temperature for sweetvetch germination would be $20^{\circ} \mathrm{C}$. Under a constant temperature of $20^{\circ} \mathrm{C}$ and dark conditions sweetvetch had nearly $50 \%$ germination in two days.

Germination response under fluctuating temperatures cannot be as clearly defined as a response to constant temperatures. A temperature $X$ light interaction was evident when temperatures were fluctuated, and at one temperature $\left(25-15^{\circ} \mathrm{C}\right)$ light produced more germination than the dark treatment. The optimum germination under fluctuating temperatures appears to be $15-25^{\circ} \mathrm{C}$ and $20-15^{\circ} \mathrm{C}$ (for 8 hours and 16 hours, respectively, in each case) under dark conditions.

Sweetvetch seed will germinate rather well under moisture stress conditions up to -7.5 bars osmotic potential. Germination response does not appear to be affected at $-0.3,-5$, and -7.5 bars. Significant reductions in germination percentages were noted at $-10,-12.5$, and -15 bars osmotic potential. The response of sweetvetch seed to osmotic stress provides some indication that sweetvetch may be moderately drought tolerant during early stages of growth. This study indicates that sweetvetch seed can germinate rather well under relatively high levels of osmotic stress if the temperature is favorable. In addition, sweetvetch seed responds quickly to favorable temperature and moisture conditions which will enable this species to take advantage of short periods of time when field conditions are suitable for germination.

The presence of a hard seed coat and resultant inability of sweetvetch seed to show imbibitional swelling in the presence of adequate water indicates a need for seed coat scarification prior to field planting. However, if field conditions are such that extremes in temperature during the winter from fall seeding, microbial activity, or abrasion by soil particle movement are adequate to weaken the seed coat and allow permeability, then scarification prior to seeding may not be needed.

\section{Literature Cited}

Fedtschenko, B. 1902. A revision of the genus Hedysarum. Acta Hortic. Petrop. 19:185-325.

Kidd, Frank A., C.P.P. Reid, and R.W. Davison. 1977. Culture growth inhibition of Ceratoides montia by induced water stress. Mycologia 69:615-618.

McGinnies, W.J. 1960. Effects of moisture stress and temperature on germination of six range grasses. Agron. J. 52:159-162.

Mexal, John, and C.P.P. Reid. 1973. The growth of selected mycorrhizal fungi in response to induced water stress. Can. J. Bot. 51:1579-1588.

Northstrom, Terry E., and Stanley L. Welsh. 1970. Revision of the Hedysarum boreale complex. Great Basin Natur. 30:109-130.

Nuttall, T. 1818. The genera of North American plants, Vol. 2. D. Hearth. Philadelphia.

Plummer, A. Perry, Donald A. Christensen, and Stephen B. Monsen. 1968. Restoring big-game range in Utah. Utah Div. Fish Game Publ. 68-3.

Redente, Edward F. 1980. Autecology of Hedysarum boreale. Ph.D. Diss. Colorado State Univ., Fort Collins. 73 p.

Rollins, R.C. 1940. Studies in the genus Hedysarum in North America. Rhodora 42:217-238.

Rydberg, P.A. 1896. Flora of the Black Hills of South Dakota. Contr. U.S. Nat. Herb. 3:463-536.

Sims, Phillip L., and Edward F. Redente. 1974. Revegetation of disturbed surface soils in various vegetation ecosystems of the Piceance Basin. Colorado State Univ., Environ. Res. Cent., Tech. Rep. 5. 157 p.

Townsend, C.E., and W.J. McGinnies. 1972. Mechanical scarification of cicer milkvetch (Astragalus cicer L.) seed. Crop Sci. 12:392-394.

U.S. Department of Agriculture. 1937. Range plant handbook. U.S. Dep. Agr. Forest Serv. 500 p. 